E3S Web of Conferences 1, 06004 (2013)

DOI: $10.1051 / \mathrm{e} 3$ sconf/20130106004

(C) Owned by the authors, published by EDP Sciences, 2013

\title{
Mercury fractionation in sediments downstream of the abandoned mine site of La Soterraña (Asturias, Spain)
}

\author{
V. Silva ${ }^{1}$, R. Fernández-Martínez ${ }^{2}$, J. Loredo $^{1}$, A. Ordoñez ${ }^{1}$ and I. Rucandio ${ }^{2}$ \\ ${ }^{1}$ Dpto. de Explotación y Prospección de Minas. Universidad de Oviedo. ETS Ingenieros de Minas. Independencia, 13. E- \\ 33004. Oviedo. Spain. jloredo@uniovi.es \\ ${ }^{2}$ Unidad de Espectroscopía, División de Química, Dpto. de Tecnología, CIEMAT. Avda Complutense, 40. E-28040- \\ Madrid. Spain
}

\begin{abstract}
Asturias (Northern Spain) has been an important mercury mining area during the twentieth century. The mining and smelting of ore has been the responsible for the large release of mercury to the aquatic and terrestrial environments in the area. The present work sought to evaluate the fractionation of mercury in stream sediments from the Caudal River basin in central Asturias by using sequential extraction. A novel five-step sequential extraction procedure was used to assess $\mathrm{Hg}$ partitioning. Total mercury concentrations varied between 12 and $443 \mathrm{mg} \cdot \mathrm{Kg}^{-1}$. Sequential extractions revealed that both Elemental $\mathrm{Hg}$ and bound to sulfide $\mathrm{Hg}$ constituted the major forms of mercury in the samples.
\end{abstract}

Key words: sediment, mercury mine, sequential extraction, mercury fractionation

\section{Introduction}

In areas where mineral extraction activities have been intensively developed, the metals concentration in soils, water and sediments are expected to be higher than the local geochemical background. In consequence, environmental problems associated with elevated concentrations of heavy metals are characteristic of the historical mining districts. High levels of metal concentrations in stream sediments are increasingly being recognised in a lot of European Rivers, and this fact is of concern due to the effects of sediments pollution on the aquatic ecosystems and the utilization of this water as source for irrigation and drinking. As stream sediments are the main contribution of particle bound metals in aquatic systems, analyses of these materials show a particular interest in detecting pollution sources. On the other side, stream sediments play an important role in the assessment of metal contamination in surface watercourses (Soares et al., 1999).

Asturias in Northwestern Spain, is a historical mercury mining district, where mining activity was developed from the Roman period ( $1^{\text {st }}$ and 2 nd centuries) until the seventies in the twentieth century when the $\mathrm{Hg}$ mining activity was definitively abandoned in the region. More than 20 abandoned mercury mine sites are scattered throughout the region, but the most important ones are located in central Asturias, in the Caudal River basin. Deposits are located in Precambrian to Carboniferous formations and although the most frequent hosted rock is limestone, some of the richest deposits are located in conglomeratic horizons or siliceous breccias in sandstones. Ore deposits appear as irregular veins, granular aggregates or impregnations in rocks, commonly associated to fractured rocks with high porosity. Mercury is present in the paragenesis in the form of cinnabar, but metacinnabar and native mercury are also occasionally found. From a hydrogeological point of view the shale can be considered impermeable, whereas limestone and sandstone are permeable formations and constitute small aquifers. Mines have been exploited by underground mining, usually by the chamber and pillars method. Smelting operations were accomplished at the most important mine sites for decades, being the ore processed on site in large rotary furnaces. As a consequence of the intense mining and smelting activity, there is an important legacy of ruins, tailings and spoil heaps.

For assessing the mobility and availability of an element in the environment it is indispensable knowing the element distribution among the solid phases in soils or sediments, which is known as "fractionation", following the recommendation of the IUPAC (Templeton et al., 2000). In this sense, sequential extraction protocols have been a very useful and 
Hg Distribution in S1

$\mathrm{Hg}$ total content: $129.7 \mathrm{mg} / \mathrm{kg}$

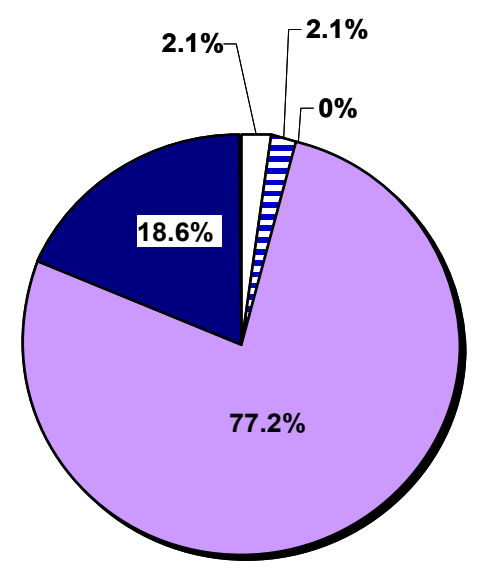

Hg Distribution in S2

$\mathrm{Hg}$ total content: $443.4 \mathrm{mg} / \mathrm{kg}$

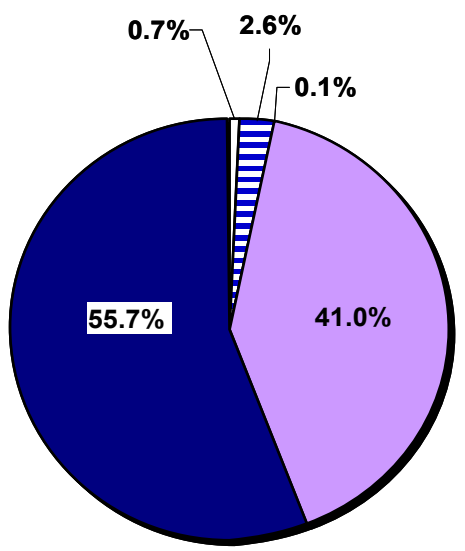

Hg Distribution in S3

$\mathrm{Hg}$ total content: $12.6 \mathrm{mg} / \mathrm{kg}$

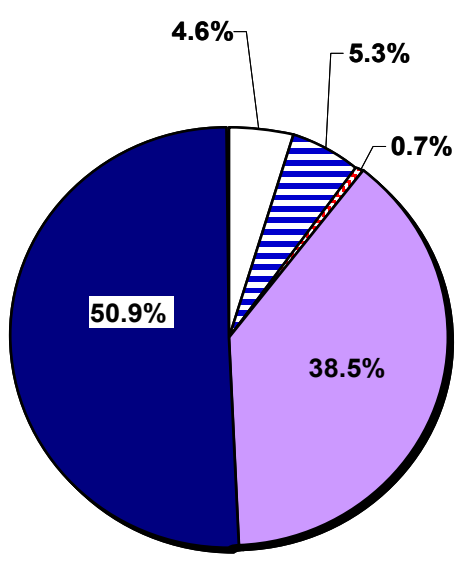

Fig. 1. Hg distribution in the different solid phases in samples studied (in $\%$ of the total content).

widely employed and recognized tool. They are based on the sequential submission of the studied sample to selective reagents of different reactivity and increasing strengths to solubilise or extract the mineral phases responsible for retaining the larger part of the studied element. Extraction steps are intended to simulate changes in the environmental conditions that could have effect on metal binding, such as acidification, oxidation or reduction (Bacon and Davidson, 2008). In the case of mercury, owed to the unique physico-chemical properties of the majority of mercury species, specifically designed protocols are usually applied to study its mobility in solid environmental samples (Issaro et al., 2009).

\section{Materials and Methods}

A selection of samples of stream sediments in sampling stations S1, S2 y S3 have been randomly collected downstream of the abandoned La Soterraña Mine
(Central Asturias). Sediment analyses for heavy metals and metalloids was carried out on the $<63 \mu \mathrm{m}$ fraction of the subsurface sediment. The data collected provide a measure of the total concentration of specific metal and metalloid constituents for each site. Each sample consisted of approximately $1 \mathrm{~kg}$ of surface layer sediment $(0-30 \mathrm{~mm})$, which was collected using a plastic scoop. All samples were pre-sieved in the field using a $2 \mathrm{~mm}$ mesh stainless steel sieve, using river water and stored in plastic sacs. Large stones and boulders were carefully removed to expose the finer sediments underneath. In laboratory, samples were oven dried at $40^{\circ} \mathrm{C}$ to prevent volatilisation of mercury. Any caking of dried samples was broken up using a pestle and mortar. The sediments were then sieved through a $63 \mu \mathrm{m}$ stainless steel sieve, and the $<63 \mu \mathrm{m}$ fraction was collected for further chemical analysis. Water samples from each sampling location were used for $\mathrm{pH}$ and conductivity analysis. The $\mathrm{pH}$ of the water at each sampling location was measured using a pHmeter, previously calibrated with standard 
buffer solutions. Although the mines located on the catchment are closed since 1974, the metal contaminants are still widespread. Iron oxides and organic matter commonly act as scavengers for heavy metals. Based on background concentrations, enrichment factors can be calculated to quantify significant heavy metal inputs above natural levels.

For this study, a specific sequential extraction method to evaluate the $\mathrm{Hg}$ geochemistry in solid samples has been applied. This methodology is based the successive application of selective extractions to quantify the $\mathrm{Hg}$ associated to different phases in the samples (Fernández-Martínez, 2006). The different fractions of $\mathrm{Hg}$ considered in the sequential extractions are: "labile $\mathrm{Hg}$ species", "Hg associated to humic and fulvic acids", "Hg associated to Fe and Mn oxihydroxides", "elemental $\mathrm{Hg}$ " and "Hg associated to sulphides".

\section{Results and Discussion}

In the figure 1 the results for samples $\mathrm{S} 1, \mathrm{~S} 2$ and $\mathrm{S} 3$ are presented.

According to the obtained results, $\mathrm{Hg}$ in sample $\mathrm{S} 1$ is mainly associated to elemental $\mathrm{Hg}$ fraction, in a percentage of $77.2 \%$, corresponding to a $\mathrm{Hg}$ content of $97.5 \mathrm{mg} / \mathrm{kg}$. Another relevant fraction in the sample is the $\mathrm{Hg}$ associated to sulphides, with a percentage of $18.6 \%$ of $\mathrm{Hg}(23.5 \mathrm{mg} / \mathrm{kg}) . \mathrm{Hg}$ content of sample $\mathrm{S} 1$ is practically represented by these two fractions and this fact is in accordance with the type of sample, as it was collected in the spoil heap. Other $\mathrm{Hg}$ fractions represented in the sample are: $\mathrm{Hg}$ labile species $2.1 \%(2.7 \mathrm{mg} / \mathrm{kg} \mathrm{Hg}), \mathrm{Hg}$ associated to humic and fulvic acids $2.1 \%(2.7 \mathrm{mg} / \mathrm{kg}$ $\mathrm{Hg}$ ), and $\mathrm{Hg}$ associated to $\mathrm{Fe}$ and $\mathrm{Mn}$ oxyhydroxides are not significant.

In samples $\mathrm{S} 2$ and $\mathrm{S} 3, \mathrm{Hg}$ is distributed mainly as $\mathrm{Hg}$ associated to sulphide. $\mathrm{Hg}$ content in this fraction is $215.2 \mathrm{mg} / \mathrm{kg}(55.7 \%$ of total $\mathrm{Hg})$ for $\mathrm{S} 2 \mathrm{sediment}$, and 7.8 $\mathrm{mg} / \mathrm{kg}(50.9 \%$ of total $\mathrm{Hg})$ for $\mathrm{S} 3$. Then, $\mathrm{Hg}$ in both samples can be considered to be in the form of particulate cinnabar transported in suspension downstream of the mining area. The second more important fraction in these samples is the $\mathrm{Hg}$ recovered as elemental $\mathrm{Hg}$, which supposes $41 \%$ of total $\mathrm{Hg}(158.5 \mathrm{mg} / \mathrm{kg})$ in sample $\mathrm{S} 2$ and $38.5 \%(5.9 \mathrm{mg} / \mathrm{kg})$ in sample $\mathrm{S} 3$.

The predominant mercury forms, bound to sulphide mercury and elemental mercuy have a relatively low solubility and persists in the medium remaining available for chemical and biological transformations. However, while cinnabar is one of the most refractory mercury forms and only can be mobilised by extreme conditions, the great abundance of elemental mercury is of concern since this species is sensitive to redox variation. Then, it may suffer oxidation to $\mathrm{Hg}$ (II) which presents great susceptibility to be solubilised, adsorbed onto mineral surfaces and even methylised by bacteria (Barejao et al., 2009).

\section{Acknowledgments}

Authors thank the Spanish Ministry of Science and Innovation (previously others) for the financial support (project CGL-2006-08192).

\section{References}

Bacon JR, Davidson CM. 2008. Is there a future for sequential chemical extraction? Analyst 133: 25-46.

Barejao, E.V.V., Bellato, C.R., Fontes, M.P.F. 2009. Mercury fractionation in stream sediments from the Quadrilátero Ferrífero gold mining region, Minas Gerais State, Brazil. Environmental Monitoring and Assessment, 157, 125-135.

Fernández-Martínez, R. Desarrollo y Aplicación de Nuevas Metodologías para el Estudio del Fraccionamiento y Movilidad del Mercurio en Muestras Medioambientales, Química Analítica y Análisis Instrumental, PhD dissertation, Universidad Autónoma de Madrid, Madrid, 2006, p. 343.

Issaro, N., Abi-Ghanem, C. and Bermond, A. 2009. Fractionation studies of mercury in soils and sediments: A review of the chemical reagents used for mercury extraction. Analytica Chimica Acta, $631,1-12$.

Soares, H.M.V.M., Boaventura, R.A.R., Machado, A.A.S.C. and Esteves da Silva, J.C.G. 1999. Sediments as monitors of heavy metal contamination in the Ave river basin (Portugal): multivariate analysis of data. Environmental Pollution 105, 311_/23.

Templeton D.M., Ariese F., Cornelis R., Danielsson L.G., Muntau H., Van Leeuwen H.P., et al. 2000. Guidelines for terms related to chemical speciation and fractionation of elements. Definitions, structural aspects, and methodological approaches (IUPAC Recommendations 2000). Pure and Applied Chemistry 72: 1453-1470. 